\title{
The Complexity of Social and Cultural Dynamics in Emerging of Collective Spaces in Unplanned Urbanisation: Learning from Mlalakuwa-Dar es Salaam
}

\author{
Jacob Lutta1*, Yves Schoonjans ${ }^{1}$, Aldo Lupala² \\ ${ }^{1}$ Department of Architecture, KU Leuven-Campus Sint-Lucas, Ghent, Urban Projects, Collective Spaces and Local Identities \\ Research Group.51, Hoogstraat, Ghent, Belgium \\ ${ }^{2}$ School of Spatial Planning and Social Sciences (SSPSS), Ardhi University, Dar es Salaam, Tanzania \\ Email: *lutjet.lutta@gmail.com
}

How to cite this paper: Lutta, J., Schoonjans, Y., \& Lupala, A. (2021). The Complexity of Social and Cultural Dynamics in Emerging of Collective Spaces in Unplanned Urbanisation: Learning from Mlalakuwa-Dar es Salaam. Current Urban Studies, 9, 445-463. https://doi.org/10.4236/cus.2021.93028

Received: June 24, 2021

Accepted: August 17, 2021

Published: August 20, 2021

Copyright (c) 2021 by author(s) and Scientific Research Publishing Inc. This work is licensed under the Creative Commons Attribution-NonCommercial International License (CC BY-NC 4.0). http://creativecommons.org/licenses/by-nc/4.0/

\begin{abstract}
The growth of African cities encountered movement of people from countryside to capital cities searching for employment opportunities. In the city of Dar es Salaam the job market has not grown enough to keep up population increase. The increasing urban population boosted the basic needs and the demand for land for various activities, posed daunting challenges for attaining liveable neighbourhoods. At the same time many of informal settlements are dynamic part of the city in physical, economic, social and cultural terms. Different programs from international organizations illustrate how sustainable urbanization can be a key contributor to poverty reduction to better quality of life. This research is based on literature reviews, documentary analysis, photographic registration and qualitative survey of the Mlalakuwa neighbourhood to provide a better understanding of the role of proactive cultural differences and social dynamics in promoting the spreading of spaces in informal settlements in the urban fabric, beyond the primarily necessary housing conditions. Researchers emphasize the importance of collective spaces for urbanisation, in social and economic terms as an important asset for quality of life and the construction of a sustainable and resilient community. The aim of this paper was to examine how social, and cultural factors cause the dynamics set up in physical collective spaces in a particular informal neighbourhood of Dar es Salaam city. The examination of human activities including social, cultural and economic functions respond to formation of spatial organisation of collective spaces at Mlalakuwa informal settlement. Notably, the paper illustrates that, the urban planning net-
\end{abstract}


work can take on significant benefits when considering cultural and social diversity as a factor that could change the whole concept of urban planning. The incentives for diverse in cultural, social and economic activities in collective spaces are vital to sustainable informal settlements because they play a major role in improving the liability of collective spaces in unplanned neighbourhoods.

\section{Keywords}

Informal Settlements, Public Spaces, Cities Growth, Tanzania

\section{Introduction}

Informal settlement phenomenon has been recently increasing rapidly in developing countries in Sub-Saharan Africa including Tanzania. The Dar es Salaam population of more than 4.5 million is made up of 120 ethnic groups of cultural and social diversity (Lupala, 2002; Nguluma, 2003; Makundi, 2014). Informal urbanisation and urban poverty are the consequences of the negative decision that are likely to be constricted by the authorities and development actors. The urbanisation in developing countries for that matter is not met with commensurate with social and cultural values during the planning process. This falls short in meeting the demands for urban growth process leading to the emerging of various public and collective spaces (UN-Habitat, 2004; Limbumba, 2010).

In the process of walking in informality, it is possible to identify tactics used by the informal settlements inhabitants to construct their environments with social and cultural understandings. The current study on informal urbanisation of Dar es Salaam is hardly focusing on a more precise understanding of social and cultural diversity in the neighbourhoods. Little is still documented with regards to the underlying development processes through which social and cultural dynamics led to the emergence of public and collective spaces in the informal settlements in Dar es Salaam.

The formal city establishes some development strategies that are often regular and predictable whereas informal citizens have to develop strategies for appropriation and adaptation of shape and spaces that related to the ones established by city (Kamalipour, 2016; Shubira \& Daniel, 2018).

This paper aims to examine social and cultural factors which cause the dynamics set up in collective spaces of informal settlements with a view to understand the role of the urbanisation process that can take a significant benefit to urban planning and design. The paper maps prevailing collective spaces imbedded with cultural and social lives that responded to existence to diversity of collective spaces in an informal settlement which brings the implication to informal urbanisation process. 


\section{Methods}

The research itself focuses on one particular neighbourhood, Mlalakuwa in the city of Dar es Salaam as primarily case study area for my PhD study. To carry out this research, the authors have adopted three main methods. Firstly, the literature review of publications and official documents is performed to understand the phenomenon of informal settlements and investigate the different academic stances and governments' responses to the challenge of emerging collective spaces in informal urbanization.

Secondly, semi-structured interviews with the representatives of groups of stakeholders, who have considerable experience in informal settlements upgrading efforts and the shaping of related policies in Tanzania helps us to grasp different opinions regarding the emerging collective spaces influence by social, cultural motifs. Thirdly, the empirical information is primarily gathered through meticulous field survey and talks with informal settlements inhabitants to collect data, photographing and mapping the various emerging collective spaces in informal areas.

\section{Conceptualising Informal Urbanisation}

Informal urbanisation ${ }^{1}$ is among of the apparent challenge in the rapidly urbanisation cities in developing world. Scholars including Turner (1967) and Hernandez and Titheridge (2015), depicting informality as a processes and activities falling outside the rules and regulations of modern formal planning which they have their own values and aesthetics that contributing to the urban development (Mng'ong'o, 2004). The emerging of informal settlement tend to violate with the existing laws, land development and housing construction Acts in the cities (Jones, 1997; Lupala, 2002; Shubira \& Daniel, 2018). Informal settlement concept can be derived from various aspects including social-cultural order, social economic drivers, housing types, land use and development pattern (Rweyemamu, 2013; Shubira \& Daniel, 2018).

Formal and informal urbanisation systems in African countries play as an important aspect in the daily life of many city dwellers and their social, cultural, and economic identities (Kombe \& Kreibich, 2006). These has been capturing the real strategy of scaling up the life of the urban poor in various dynamics and subsisting social-spatial policies, political and economic and the whole process of everyday life in the urban settings (Kombe, 2017; Shubira \& Daniel, 2018). Base on the discourse of informality, the informal settlement is merging in spatial terms which cover more than 80 percent of inhabitants in developing cities are residing in informal areas (UN-Habitat, 2011).

UN-Habitat (2011) and Millennium Development Goal 7 (MDG7) emphasizing the role of scaling up liveability to informal dwellers through provision of infrastructure and empowering community to involved in development process

${ }^{1}$ In this paper informal urbanisation is referring to informal settlements. 
(Marete, 2016). But at the same time, they stress the importance of public and collective space on having a great impact on that development process since they can foster social actions by the different groups in the neighbourhood, making it a real neighbourhood as well as help to articulate and emphasize the human basic needs (Fao, 2008).

In the new urbanism theory human basic needs have been depicted as important areas that providing connection and interactions to human by considering social, economic and cultural aspects (Katz, 1994). Later in the article we will describe the term collective spaces and its agency. Figure 1 depicts Informal urbanisation in Tanzania's which has the unique characteristic to be a habitable place hosting a mixture of low and middle income earners living in the pattern of low density and low rise urbanisation (Lupala, 2002).

Since early 1990s' there is tremendous increase on informal urban development enhancing diversity of spaces with various functions which consist of a wide range of social-cultural and socioeconomic groups. The idea brought by

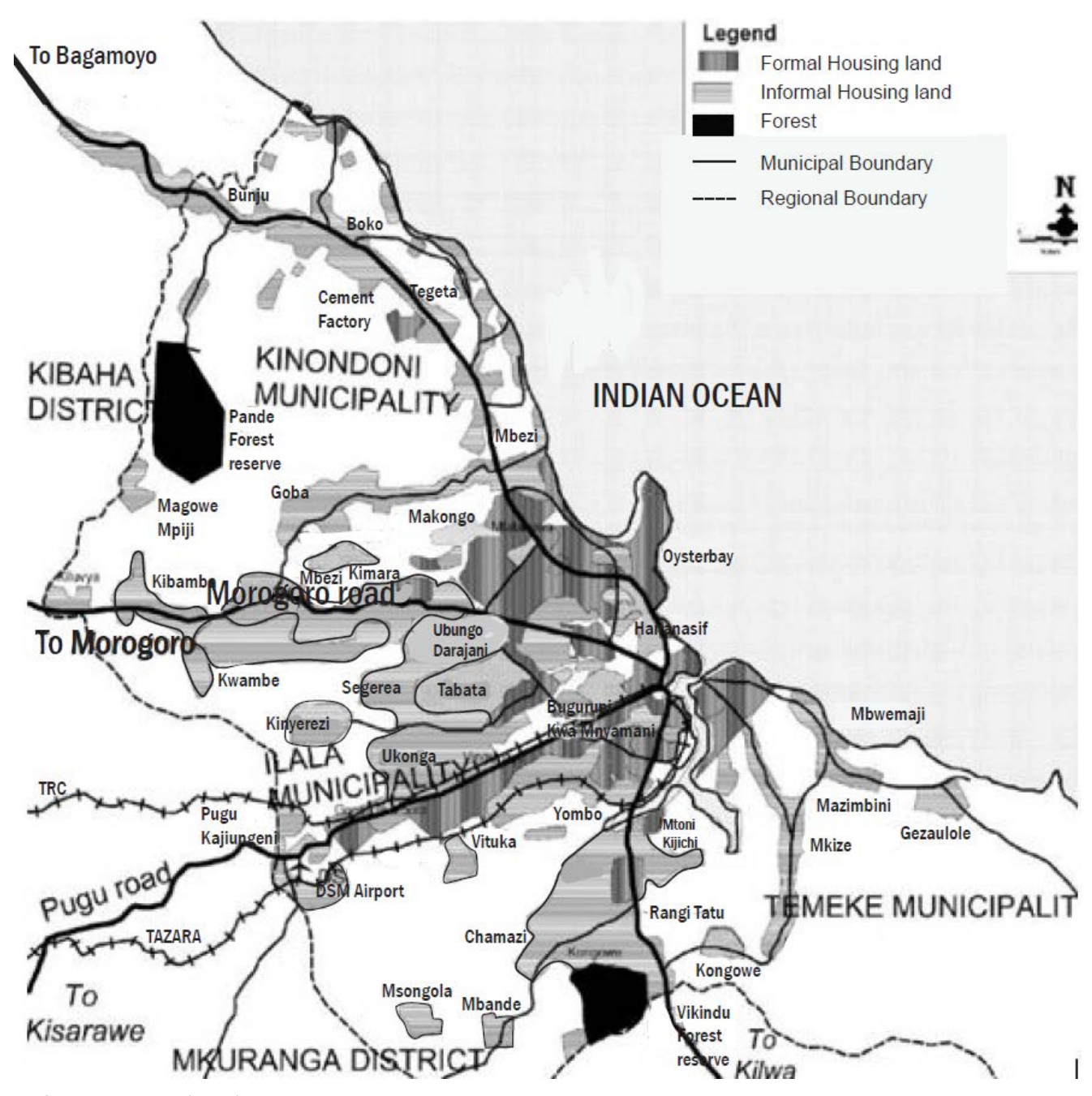

Source: Kyessi (2002).

Figure 1. Distribution of Formal and Informal settlements in Dar es Salaam city. 
Paul Jones (2014) is to connect new development process and meaning that permeate all aspects of informal settlements lives, social-cultural and identity for the purposed of creating new design that will reflect the really lives of the communities within informal urbanisation (Jones, 2014).

\subsection{Social-Cultural Value in the Growth of Informal Settlements}

Despite the numerous definitions and interpretations of cultural concepts the ideas align with the creation of shared and common believe and values that helps to define the community common behaviour (Gutierrez de Peneda, 1975; Kellect, 1999). Social anthropologist underlines the importance of viewing social-cultural values that will help to understand behaviour of the community (Saunders, 1989). Social and cultural practises are essential elements in the urbanisation process since they bring stability and meaning to human preponderance that contributes to the quality of use of emerging public and collective spaces in informal urbanisation.

However, social-cultural values act as drivers of developments in its own way and desirable outcome of the political, and social economic development (Kellect, 1999). According to United Nations General Assembly (2011) the attention has made by integrating the mainstreaming of social and cultural values into development policies and strategies to all levels (UNGA, 2011). The powerful development can be valued if social-cultural process that have been followed in the great care and sensibly in planning, development and management to acquire the human wellbeing (Phillips, 2002).

\subsection{Collective Spaces Ideology}

The term 'Collective Spaces' has been defined differently as per location and context. Some researchers depicts the importance of collective spaces and coming up with their ideologies of collective space as intermediate common spaces for public and private use in the urban layout (Gurney, 1990). The collective spaces have significant in the growth of the city in the sustainable way (De SolàMorales, 1992). Debord (1981) elucidated that, "However, most of the sociologists point out the particular activities all over the place and day to day life is nowhere." Lefebvre (1991) admits spaces accounted by the habitants and the surroundings. Therefore collective spaces in is a full and coherent that testifies to a glorious tradition of public life with its levels of appropriateness (Scheerlinck, 2013).

Collective spaces provide platform in informal urbanisation in any case to share and practise a common cultural and social values that portraying vernacular identity of the environments (Borret, 1996; Kellect, 1999). To generalise collective spaces comprehend how society behave culturally, socially as factors leading to spatial settings in the context of informal urbanisation (Muke et al. 2007; Schoonjans \& Zhang, 2020). 


\section{Informal Settlements Practise in Tanzania}

Tanzania National Bureau of Statistics report of the year 2012 by indicates that more than 29.5 percent of the country's population resides in urban centers, an increase to 35 percent in the year 2019 (URT, 2013). The World Development Report (2020) recent report indicates an annual urban population growth rate of 4.9 percent. And these have an effect with the growth of urban informal settlements in Dar es Salaam has been ascribed to rapid urbanization (Lupala, 2002; Nguluma, 2003; Kombe \& Kreibich, 2006).

According to World Development Report (2020) in the understanding informal settlement tragedy, various policies implemented by the authorities of Tanzania with the intention to tackle informal settlements challenge. The National Land Act of 1995 provides the opportunity for the informal settlement to be recognized in the cities and to have room to be improved (URT, 1999; Makupa \& Alananga, 2018). The local government Urban Act of 1982 is also stipulated the Local government should consider the availability services and facilities in the informal areas. Not only that but also the National Land Act provides the opportunities for the land ownership for the period of not more than 99 years (URT, 1999).

Rural villages in many cities in Tanzania experiences the persistence of squatter, unplanned, and informal settlements that exhibit the physical, social, and socio-cultural characteristics of rural villages (Figure 2(a)). These features has

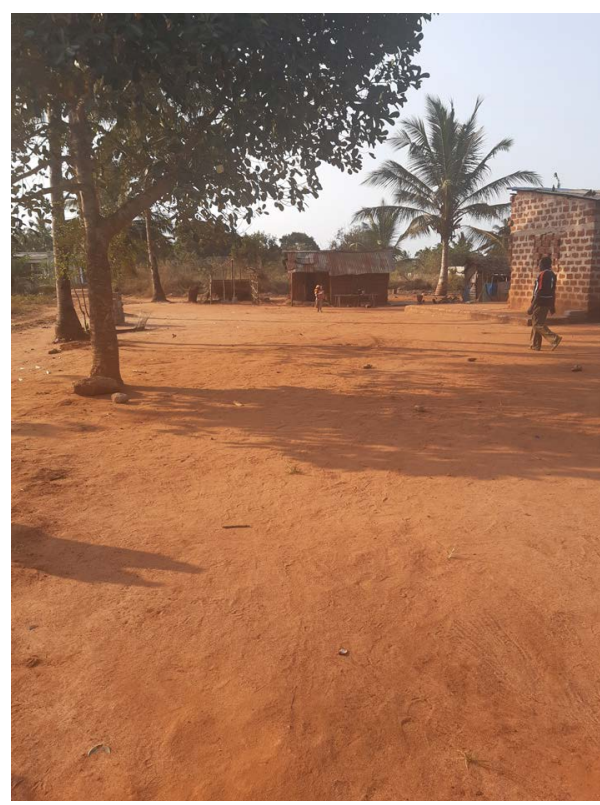

(a)

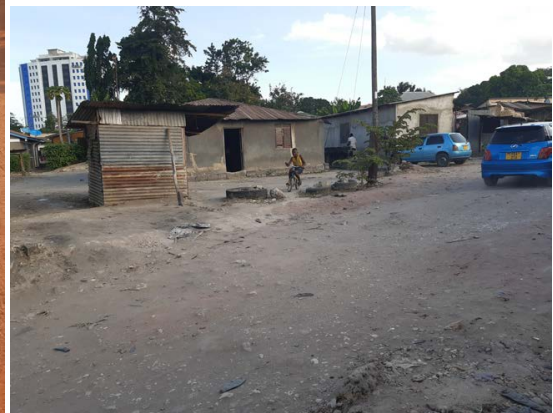

(b)

Source: Author's Fielddwork, 2020.

Figure 2. Simlarities between informal settlement in rural area and informal settlement in urban area in the city of Dar es Salaam. (a) Image shows Informal settlement at Chanika Lubakaya in Ilala district approximately than $45 \mathrm{~km}$ from CBD; (b) One of the informal settlement street at Mlalakuwa neighbourhood approximately less than $10 \mathrm{~km}$ from CBD. 
even found to appear even within an urban settings (Figure 2(b)) the emanating of informal urbanisation (Lupala, 2002; Nguluma, 2003; Wenban-Smith, 2014).

The increasing number of immigrants from rural areas to big cities mainly Dar es Salaam (Figure 3), makes people shifting with their traditional, cultural and social images in their mind (Abebe, 2010; Makundi, 2014). These create unique identity often developed as enclaves, being characterized by inhabitants who migrated and retained strong ties to particular social, cultural, and traditional elements from rural area (Lupala, 2002; Limbumba, 2010). However, such the phenomena of the "rural village in the city" dominate the urban development in many African cities taking example of Dar es Salaam city (Sheuya, 2010; Limbumba, 2010).

Inhabitants from coast zone Morogoro, Dar es Salaam, and Coast region are engaged with agricultural, forest, fishing and other key coast activities which are very important contributor for the flourishing their traditional, social-economy and cultural identities (Pallangyo, 2007; Luhikula, 1998). (Figure 4) one of the example from Ndengereko, Matumbi and Nyagatwa Ethnic groups residing in the coast region elucidating the mode of housing within the clan layouts and collective spatial settings based on informal, squatter depending to their daily routine
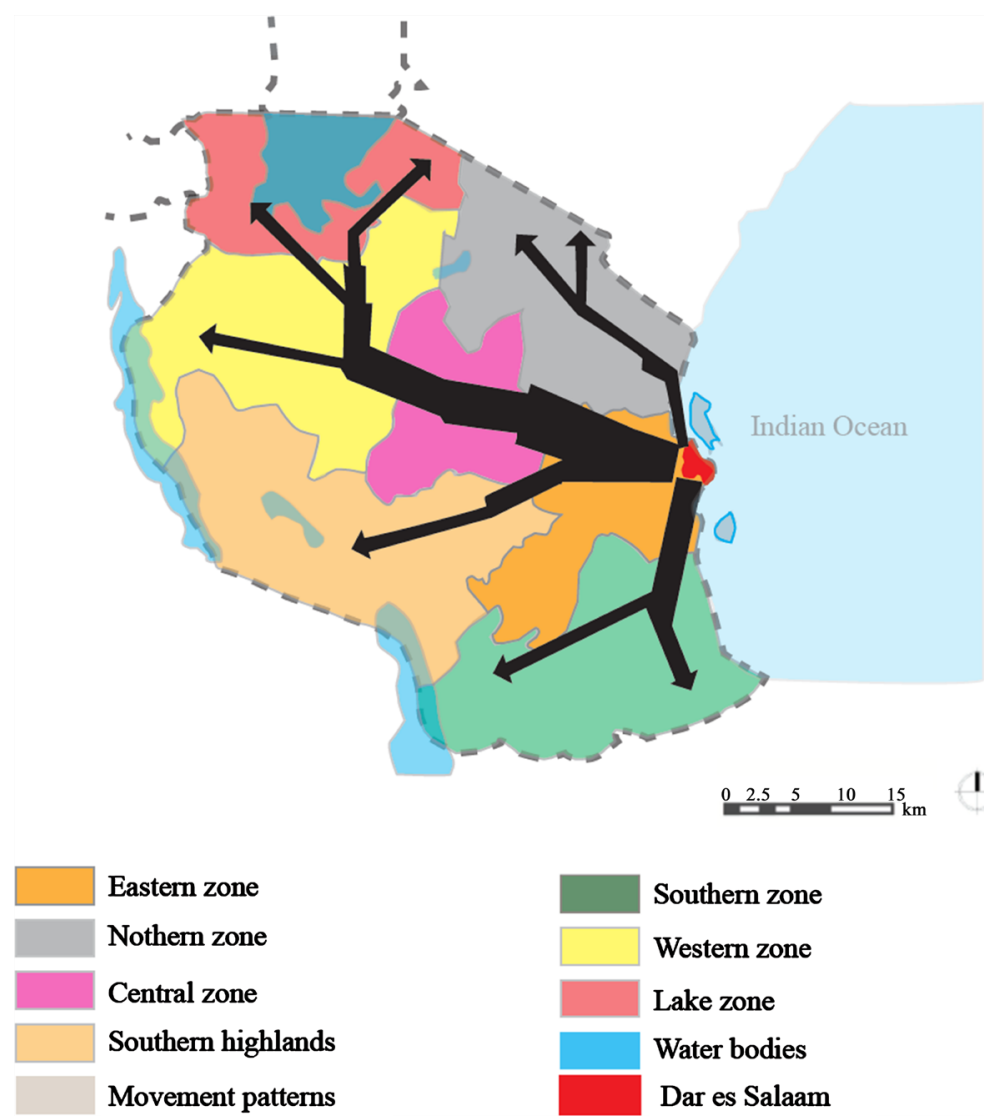

Source: Adopted from https://ibgeo14.weebly.com.

Figure 3. Map of Tanzania showing administrative zones and rural immigration pattern to Dar es Salaam city. 
that defined and use of spaces (Kruse \& Torstensson 2011; Swantz, 2013). It is found that more than 68 percent of the mainland population of Tanzania is still rural, with the majority engaged in subsistence farming for their own or very local consumptions (Luc et al., 2018). This made them to have more spaces with dispersed spatial layout of housing to accommodate spaces for agricultural activities, social-cultural activities and dwelling spaces within the same area (WenbanSmith, 2014).

For a long time the city of Dar es Salaam coloured by rapid social and economic change including the emerging the diversity use of public and collective spaces in informal settlements this contributed by weak and non-relevant formal local governance, institutions and policies being unable to contribute to the improvements. The emphasis by those taking up a life in settlements remains unfocused that promote the growing of diversity collective spaces in the informal urban settings. This includes adjusting the basic building designs that reflects sociocultural elements from rural areas that play out at wider in towns and cities (French et al., 2011).

Table 1 summarizes typical common village norms, values, practices and attitudes

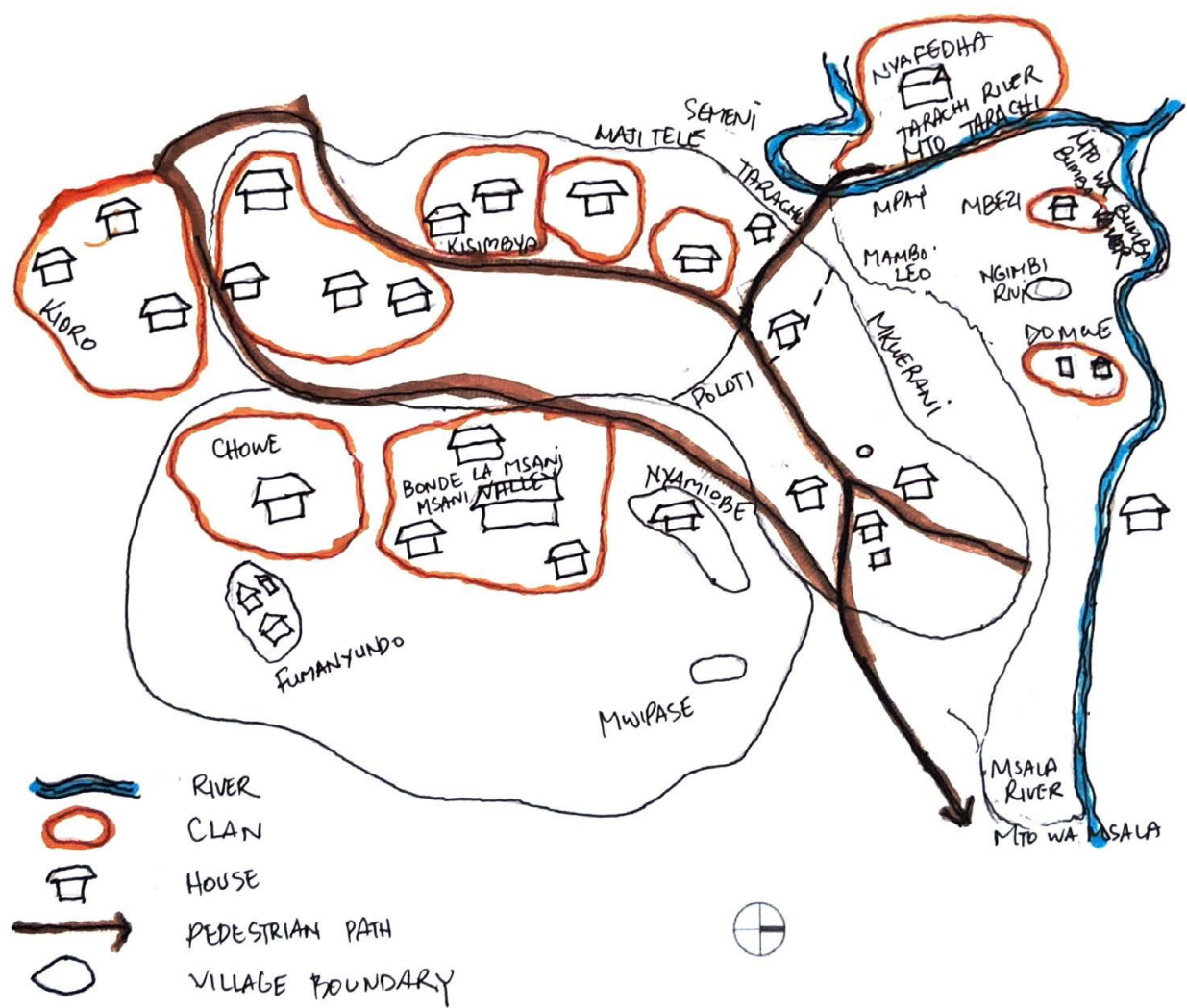

Source: Adopted from Duvail and Hogan (2005), Apport de la cartographie à la gestion locale des ressources renouvelables dans les villages du district de Rufiji (Tanzanie) ${ }^{2}$.

Figure 4. Sketch map Describing housing Layout of Ndengereko, Matumbi and Nyagatwa Ethnic group from Eastern zone-Rufiji District in Coast region.

${ }^{2}$ Édition électronique URL: http://journals.openedition.org/norois/410 [accessed 12/10/2020]. 
Table 1. Common features that build up social and cultural identities in urban area in Dar es Salaam.

\begin{tabular}{|c|c|c|}
\hline $\begin{array}{l}\text { Social and cultural } \\
\text { values }\end{array}$ & $\begin{array}{l}\text { Common norms, values, attitude and aspiration } \\
\text { expressed in rural areas. }\end{array}$ & $\begin{array}{l}\text { Common norms, values, attitude and aspiration } \\
\text { expressed in urban areas. }\end{array}$ \\
\hline \multirow[t]{7}{*}{ 1. Land occupation } & $\begin{array}{l}\text { Primarily existing of customary land ownership in rural } \\
\text { areas. }\end{array}$ & $\begin{array}{l}\text { Informal arrangements on use and 'ownership' on customary land } \\
\text { to those outside families. } \\
\text { Formal arrangement and ownership also exist. }\end{array}$ \\
\hline & $\begin{array}{l}\text { Family and wider group such as clan involved in land } \\
\text { distribution. }\end{array}$ & Oral and written arrangements to secure land. \\
\hline & Land rights oral - not recorded in writing. & Land can be leased, bought or customary \\
\hline & Land use rights not definitive & Land has greater economic use and value \\
\hline & Lands associated with families, clans and tribes & $\begin{array}{l}\text { Land ownership can be endorsed by courts and recorded in } \\
\text { registers }\end{array}$ \\
\hline & & Land used as a commodity \\
\hline & & Individual clan, group and individual title can be given to land. \\
\hline \multirow[t]{3}{*}{ 2. Habitation } & $\begin{array}{l}\text { Traditional design - for example outdoor food } \\
\text { preparation areas, toilet and bath areas, storage and } \\
\text { cattle house located away from main the building. }\end{array}$ & $\begin{array}{l}\text { Indoor kitchens, and toilets other builds functional spaces being } \\
\text { separated from main building. }\end{array}$ \\
\hline & Building structures reflect functionality of the spaces. & Connected to modern services including in house toilet system \\
\hline & Sanitation separate and away from family and house & Sanitation included to house \\
\hline \multirow[t]{6}{*}{ 3. Settlement layout } & $\begin{array}{l}\text { Dwellings in contained village arrangement in a } \\
\text { dispersed layout }\end{array}$ & Written rules and regulations for land allocation and house siting. \\
\hline & Traditional layout of buildings & $\begin{array}{l}\text { Formal and informal still exist. } \\
\text { Informal way of building arrangement with poor infrastructure } \\
\text { network }\end{array}$ \\
\hline & Low density, minimal or no reticulated services & High density, walkable \\
\hline & Limited transport systems & High environmental degradation \\
\hline & & Greater flexibility of movement \\
\hline & & High urban security, law and order Concerns. \\
\hline \multirow{5}{*}{$\begin{array}{l}\text { 4. Economic } \\
\text { activities } \\
\text { and development }\end{array}$} & Development based on farming which varying scale. & Greater need for cash for survival \\
\hline & $\begin{array}{l}\text { For some, work only carried out as needs have to be } \\
\text { met. }\end{array}$ & $\begin{array}{l}\text { Varying levels of informal and formal sector employment and } \\
\text { opportunities }\end{array}$ \\
\hline & Informal sector employment & Residents have some or self-employed. \\
\hline & Little regulation & Reliance on local produce - imported goods \\
\hline & & Rules and laws impact on business opportunities \\
\hline \multirow[t]{2}{*}{$\begin{array}{l}\text { 5. Laws and } \\
\text { Order }\end{array}$} & $\begin{array}{l}\text { Clan rules and Village administration authority and } \\
\text { controls }\end{array}$ & $\begin{array}{l}\text { Formal system rules and controls maybe acknowledged but many } \\
\text { times ignored }\end{array}$ \\
\hline & & Rules and controls set by settlement Committees (Local authorities) \\
\hline $\begin{array}{l}\text { 6. Communication } \\
\text { (Language) }\end{array}$ & $\begin{array}{l}\text { Own dialect in homogenous } \\
\text { groups }\end{array}$ & $\begin{array}{l}\text { Exposure to Swahili as a first official communication language. } \\
\text { Dialects mixed with Swahili } \\
\text { Exposed to English as another official language. }\end{array}$ \\
\hline
\end{tabular}

Source: Adopted from Kellect (1999) and Limbumba (2010) and developed by author.

that gives distinctiveness features of the settlements. This also can be viewed that their daily life and activities to have a wide chance to contribute in the modification of the collective spaces and environments of the local dwellers. However, 
the process of operation of social and cultural values including land ownership, housing, settlements layout, development of economic activities and law and order are the key element that enhancing morphology of collective spaces in rural and urban centers.

\section{Findings}

\subsection{Naming and Places Identification}

The study revealed that growth of rural areas in Sub Saharan African is different as in urban centers where are the elements like public spaces and built up areas are being considered in the process of city planning (Myers, 2011; Parnel \& Pieterse, 2014). In Tanzania the master plan before and after independence has not giving out a positive effect in the planning process (Kironde, 1995). In many cases in rural areas, sense of master planning was not yet being reached, even today. However, planning was done by land distribution for agricultural, social and cultural activities through Chiefs who were local leaders (Kruse \& Torstensson, 2011; Swantz, 2013). Seemingly local leaders are the ones who practising land distribution.

Events and elements in rural areas influences the growth of spaces in many villages this including village landmarks like rivers, big trees, mountains and others. The study revealed that in the city of Dar es Salaam places have been growing and identified by reflecting the idea from rural areas. An interview conducted to one of the famous Survey streets at Mlalakuwa informal settlement to explore how the place became to be called Survey and respondent narrated that:

"The place came to be named by residents themselves because of surveyors from Surveying Institute currently Ardhi University. After the establishment of Survey Motel came to accommodates some foreign students who studying at Ardhi University made the place popular around Mlalakuwa neighbourhood ${ }^{3}$.

The study showed that, the Mlalakuwa settlement, has famous collective points like Mama Kamche bar ${ }^{4}$, Kwa Roberts ${ }^{5}$ Bar, Migombani Bar, Makondeko kwa $K^{K i d e v u^{6}}$ these places have been developed and named using the names of the owners (Figure 5). For instance, Survey Motel this is famous motel that established and identified collective areas because of surveyors from Ardhi institute (Figure 6(b)). Mlimani DDC park is dancing hall for is the Most popular Tanzanian Music band ${ }^{7}$ (Figure 6(a)).

\footnotetext{
${ }^{3}$ An interview with Mlalakuwa resident who started his life at Mlalakuwa since 1987. ${ }^{4} \mathrm{Kwa}$ mama Kamche is a lady who is the name of the owner of the bar.

${ }^{5} \mathrm{Kwa}$ Robert also is the owner of the place in another name is (Kwa mama chambo).

${ }^{6}$ Makondeko kwa Ndevu is a place for selling local brew and the place is known kwa Ndevu at Makondeko area in Mlalakuwa neighbourhood.

${ }^{7}$ DDC Mlimani Park Orchestra (Mlimani Park for short) has been one of the most popular Tanzanian muziki wa dansi bands (in Swahili).
} 


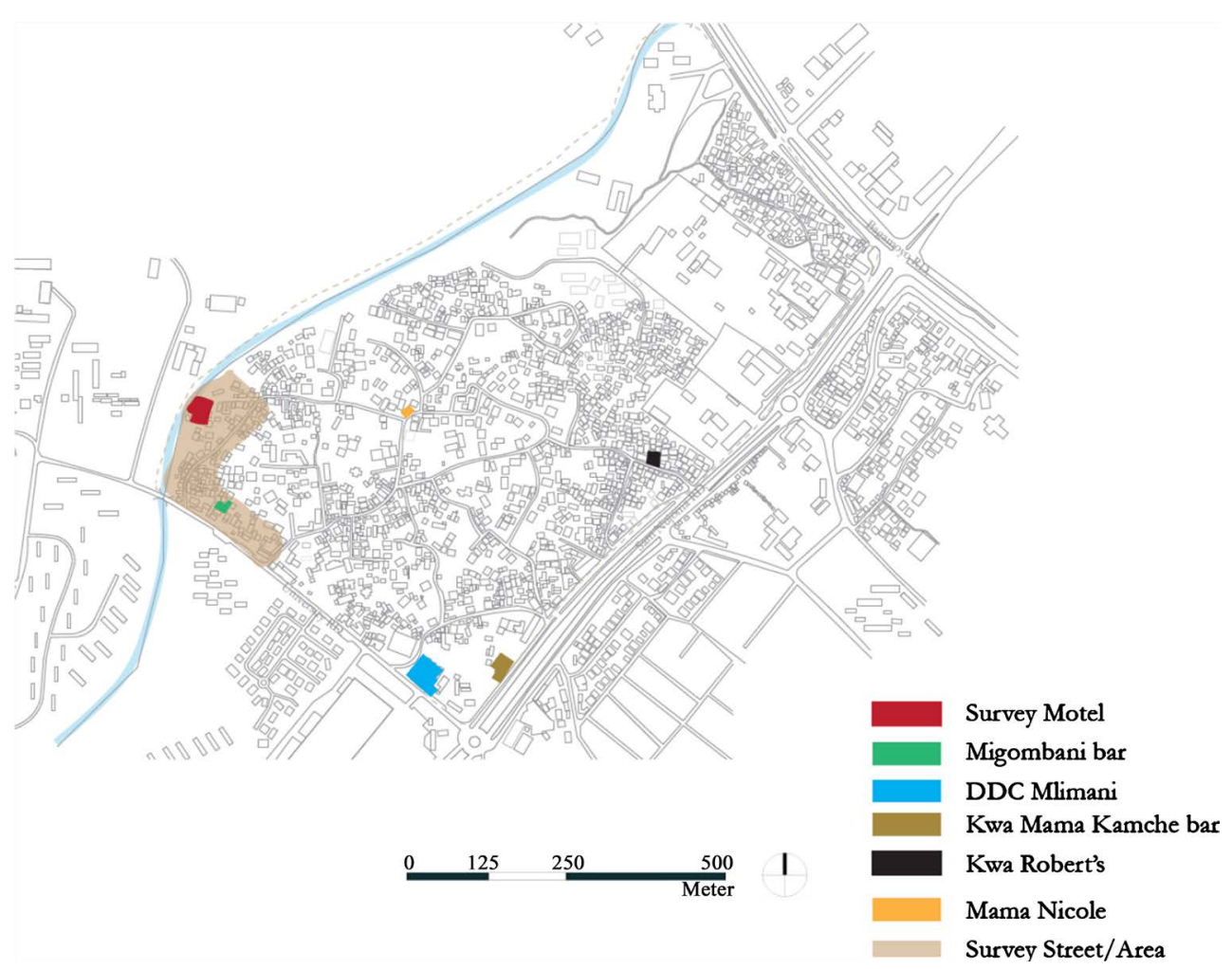

Source: Adopted from google map and Edited by Author, 2020.

Figure 5. A map showing distribution of collective spaces that identified using the name of the owners and activities that found at those areas.

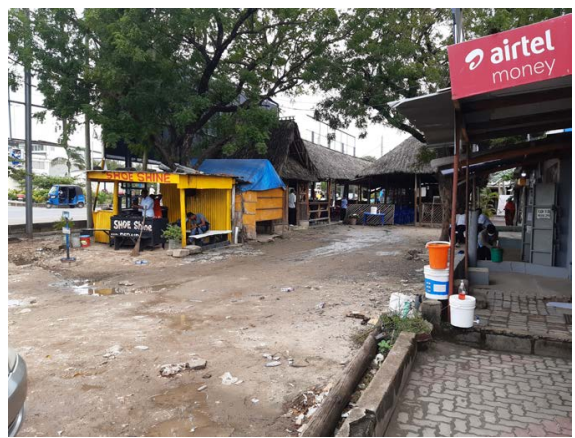

(a)

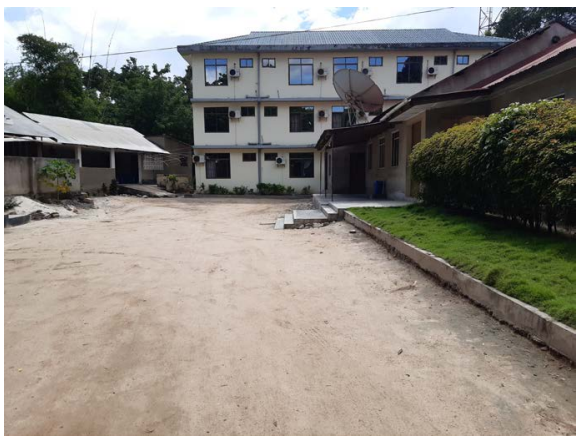

(b)

Source: Author's Fieldwork 2020.

Figure 6. Showing collective points at DDC Mlimani park and Survey Motel. (a) DDC Mlimani restaurant; (b) Survey Motel at Mlalakuwa area.

The areas became important reference points for the growth of public and collective spaces at Mlalakuwa informal settlement.

\subsection{Development of Various Collective Spaces at Mlalakuwa Area}

Collective spaces at road reserve areas

It is observed that the diversity of forms of collective spaces and their uses. (Table 2) illustrates the collective spaces adapt action by the dwellers to suit vari- 
ous functions in informal settlements areas. However, the formation of collective spaces reflects the cultural and social values which varies among of ethnic groups from different admirative zones in Tanzania (Table 2). It shows that inhabitants who are living under extreme space limitations, have been able to creatively adapt available spaces to fit their needs making collective spaces that serve both individual and collective functions (Figure $7(\mathrm{a})$ ). "Mtaa Executive Officer" $\mathrm{MEO}^{8}$ at Mlalakuwa neighbourhood, in one of the interviews, he claimed that:

Table 2. Types and use of collective spaces.

\begin{tabular}{|c|c|c|c|c|c|c|c|c|c|}
\hline \multirow[b]{2}{*}{ Activities } & \multicolumn{9}{|c|}{ Collective paces usage } \\
\hline & $\begin{array}{c}\text { Road reserve } \\
\text { areas }\end{array}$ & $\begin{array}{l}\text { Open } \\
\text { spaces }\end{array}$ & Streets & Alleys & Courtyards & Verandas & Corridor & Stair cases & Room \\
\hline Cooking & & & & & $\mathrm{x}$ & $\mathrm{x}$ & $\mathrm{x}$ & $\mathrm{x}$ & $\mathrm{x}$ \\
\hline Eating & $\mathrm{x}$ & & $\mathrm{x}$ & $\mathrm{x}$ & & $\mathrm{x}$ & $\mathrm{x}$ & $\mathrm{x}$ & $\mathrm{x}$ \\
\hline Gathering & $\mathrm{x}$ & $\mathrm{x}$ & $\mathrm{x}$ & & $\mathrm{x}$ & & & & \\
\hline Sleeping & & & & & $\mathrm{x}$ & $\mathrm{x}$ & & & $\mathrm{x}$ \\
\hline Resting/games & $\mathrm{x}$ & $\mathrm{x}$ & & & $\mathrm{x}$ & $\mathrm{x}$ & & $\mathrm{x}$ & $\mathrm{x}$ \\
\hline Washing & & $\mathrm{x}$ & $\mathrm{x}$ & & $\mathrm{x}$ & $\mathrm{x}$ & & $\mathrm{x}$ & \\
\hline Praying & & $\mathrm{x}$ & $\mathrm{x}$ & & & & & & \\
\hline Income generating activities & $\mathrm{x}$ & & $\mathrm{x}$ & & & $\mathrm{x}$ & & & \\
\hline
\end{tabular}

Source: Authors' elaboration, Field survey, 2020.

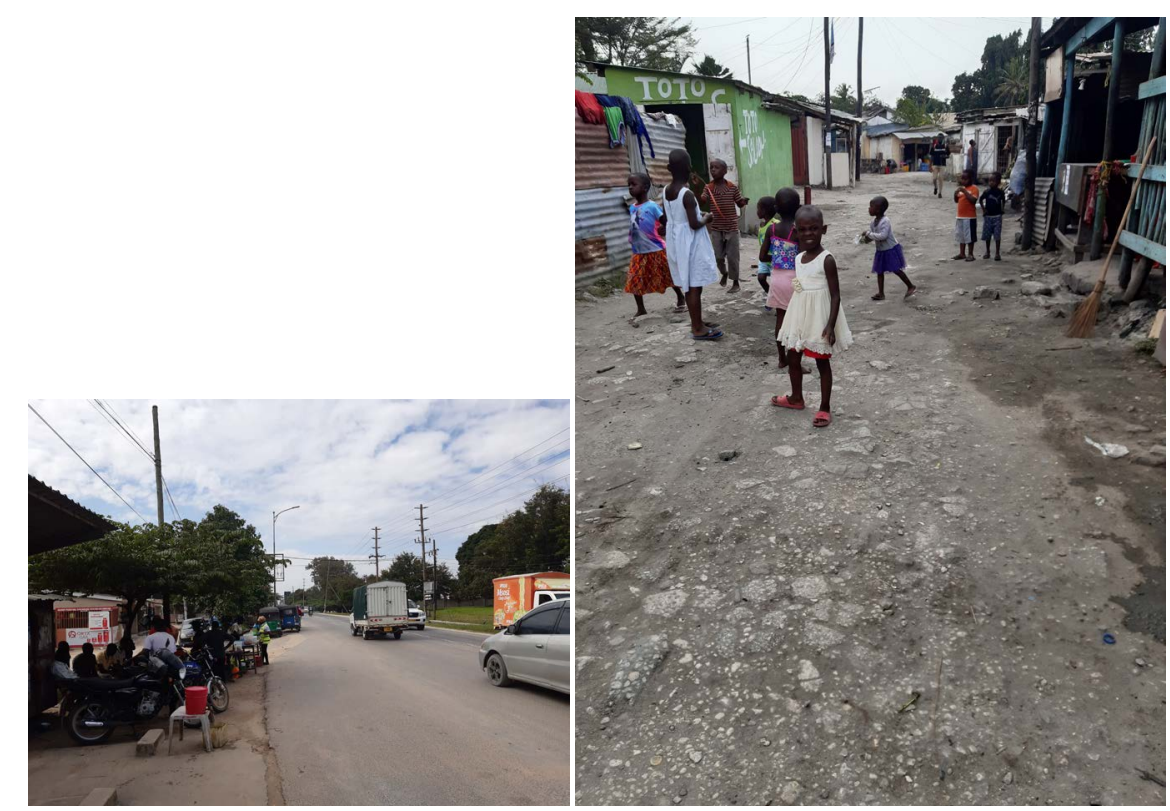

Source: Author's fieldwork 2020

Figure 7. Showing different activities at main streets and arterial streets. (a) University Road; (b) Survey street.

${ }^{8}$ Mtaa Executive Officer: An Executive Officer for Mtaa or Street is a part or a division of a ward and includes a part or a division of a township situated within an area under the jurisdiction of an urban authority MEO is appointed by Municipal Director. Local Government administrative appointee under Prime Minister's Office, Regional Administration and Local Government. 
“In actual fact we don't have public spaces here at Mlalakuwa neighbourhood people are using public spaces located outside Mlalakuwa area. As you can see people are using road reserve areas as a collective space to perform activities like economic and social activities as well as meeting points"9.

\section{Collective spaces at alley, private open spaces}

It is observed that mostly common collective spaces areas are being used to the outcome of unused or neglected of official boundaries ${ }^{10}$ with the essence of creation of functional spaces. This has been seen like alleys which meant to provide connectivity and promote permeability within informal neighbourhood, have been altered to accommodate other functions within it. Observations revealed that residents used it for commercial and other domestic activities purposes. Children's enjoy alleys for gathering and playing different games as observed to (Figure $7(b)$ ). Alleys were seen to have multiple function including social and economic purposes. Figure 8(a) depicts children playing at alley and (Figure 8(b)) commercial activities taking place at alley. Private owned open spaces also are common spaces for gathering, where locals relaxed or discussed sports and community gatherings. These spaces they exist because owners are willing to provide those spaces for community purposes (Figure $8(\mathrm{c})$ ). All these collective spaces are adjusted to reflect social and cultural needs of a place. One resident named Richard Kiumbe, during interview to the use of spaces at sleeping boundaries, stated:

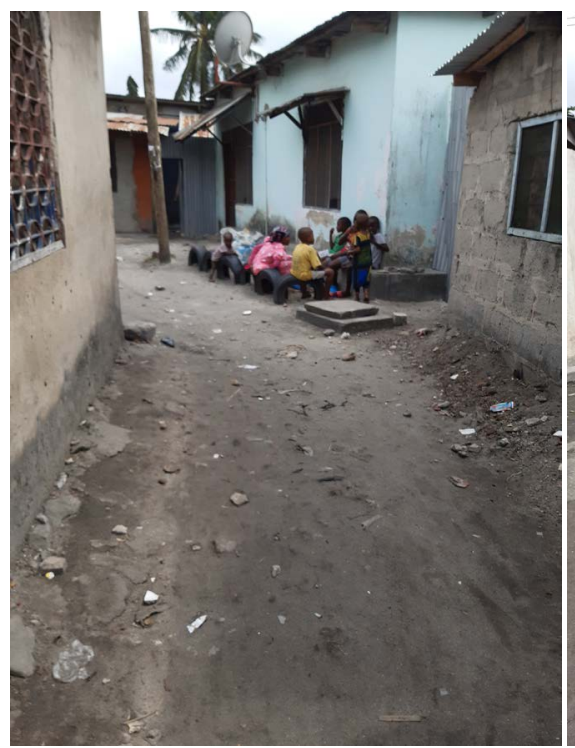

(a)

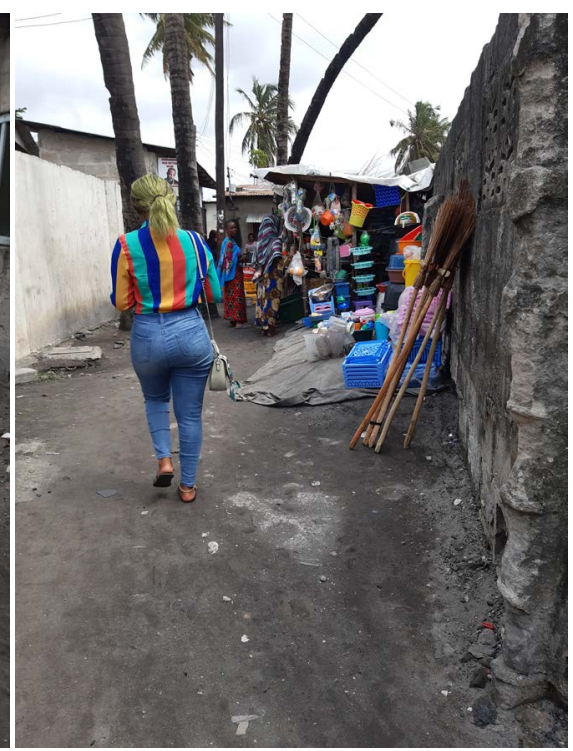

(b)

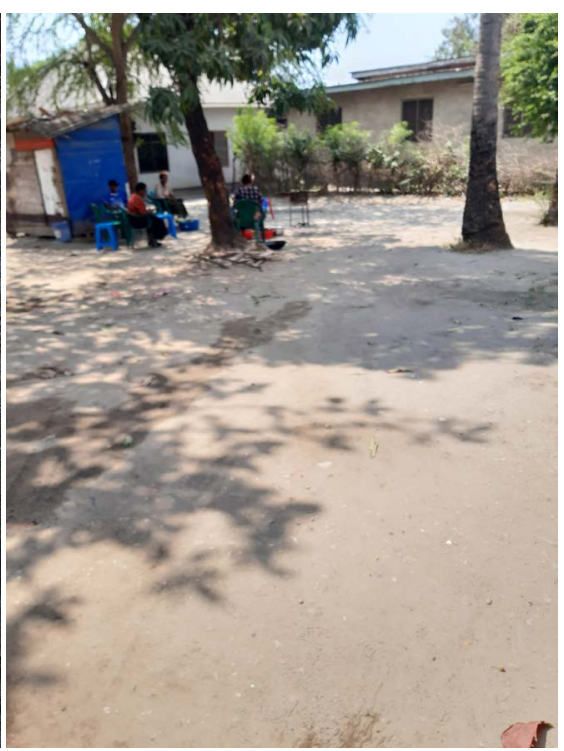

(c)

Source: Author's Fieldwork 2020.

Figure 8. Function of alleys in the informal Settlement. (a) children playing at alley; (b) Commercial activities at alley; (c) Collective space for conversation.

\footnotetext{
${ }^{9}$ An Interview with MEO on June, 2020.

${ }^{10}$ Sleeping boundaries: These are unfunctional boundaries they provide opportunity for the informal and formal dwellers to use the existing spaces.
} 


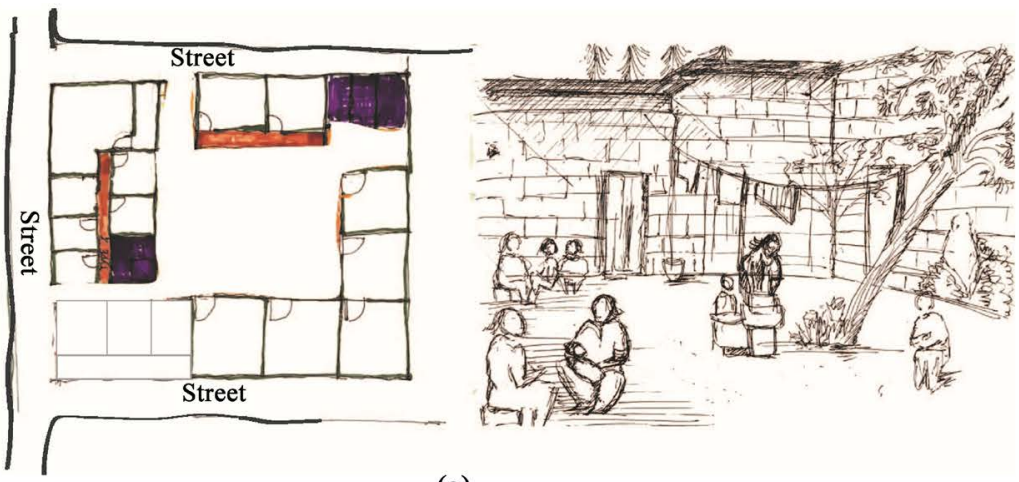

(a)
"We are using spaces that belongs to someone else even the government knows about it and allow us to do activities here like commercial activities, social activities as long as some of us are paying taxes we have no any problem. And the other hand the owners get advantage of security out from using these spaces". ${ }^{11}$

\section{Collective spaces at Domestic spaces: Courtyard ${ }^{2}$ and veranda}

The courtyard and veranda are very important areas for social and cultural significance. Some residents were observed mostly women, used the courtyard for gathering, praying food preparation area and as a domestic space for small-scale income generation activities as livelihood support (Figure 9(a)). It has observed that front veranda is mostly common collective spaces for men to exchange ideas and to discuss sports. In the Swahili culture residents use veranda as collective spaces for worship, playing bao ${ }^{13}$, draft games and dining place during the Month of Ramadhan. Islamic religion believes that using veranda as eating place could help to invite others who are in need and the owner of the house get blessings from God (Figure 9(b)). During interview Mzee ${ }^{14}$ Mohamed said:

"Hey! Young man we are living because of thanks giving to God, we Muslims believe that no one has ever become poor because by helping people. We are healthy because of giving and its more important to help people during the Month of Ramadhan you will get more blessings from God. This is the reason that we are use front Barraza ${ }^{15}$ to well come people who they don't have food to eat (Mzee Mohamed)"16

Source: Author's Fieldwork 2020.

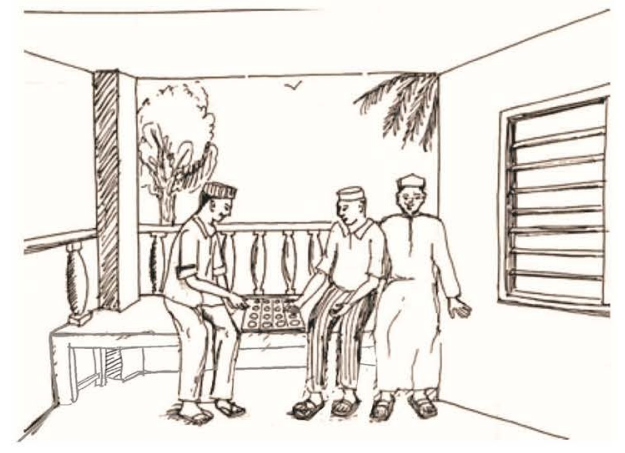

(b)

Figure 9. Showing types of collective spaces. (a) Collective spaces at courtyard area; (b) Collective spaces at veranda.

\footnotetext{
${ }^{11}$ An interview with Mlalakuwa resident on August, 2020.

${ }^{12}$ Courtyard this is the combination of different domestic spaces which resulted to enclosed spaces in the form of courtyard. It was not designed to be court yard it came out after the process of construction.

${ }^{13} \mathrm{Bao}$ game is a traditional mancala board game played in most of East Africa along the coast of Indian Ocean including Kenya, Tanzania, "Bao" is the Swahili word for "board" or "board game". ${ }^{14}$ Mzee in Swahili means a Tittle of respect to anyone older than oneself including parents.

${ }^{15}$ Baraza in Swahili means council. It's a place for meeting.

${ }^{16}$ The interview done on $16^{\text {th }}$ May 2020.
} 


\section{Collective spaces at rooms and corridors}

In addition, similar collective spaces developed by having multiple functions within the house where inhabitant rent rooms and share corridor as a common space. Corridors had multiple uses like cooking, conversation, children playing area and passage (Figure 10(a)). Because of unaffordability of renting houses low income inhabitants use lounge and room for multiple functions including family gathering, cooking, Tv watching room and sleeping. It has been found that low income earners who are living in informal settlements have extended families. Extended families have been predominant issue in informal urbanisation where by relatives from rural moving to city centers had to start their lives to their siblings and found houses being crowded. Therefore, during night time lounge changes to sleeping room and during day time it turns to normal function as a lounge (Figure 10(b)). This couldn't be inferred that the lounge/room was both recreational and sleeping space, which reinforces resident's daily adaptations to meet basic social-cultural values of the local needs.

\section{Conclusion}

This paper provides the understanding of the contribution of complexity of social and cultural values that lead to the emerging collective spaces in the informal neighbourhood of Mlalakuwa in Dar es Salaam. The paper highlights the life experiences from rural areas with their common norms, social, traditional and cultural values including informal activities and how they are transferred to cities and practices as a driving force to the formation of dynamics of collective spaces in informal settlements. Furthermore, the paper offers an important perspective on understanding social and cultural values that can be linked in design and construction practices to enrich cultural and socio-spatial quality of the design.

This narrative has exposed problematic conditions and hidden resident activities, satisfaction and social-cultural living experiences that contribute to the

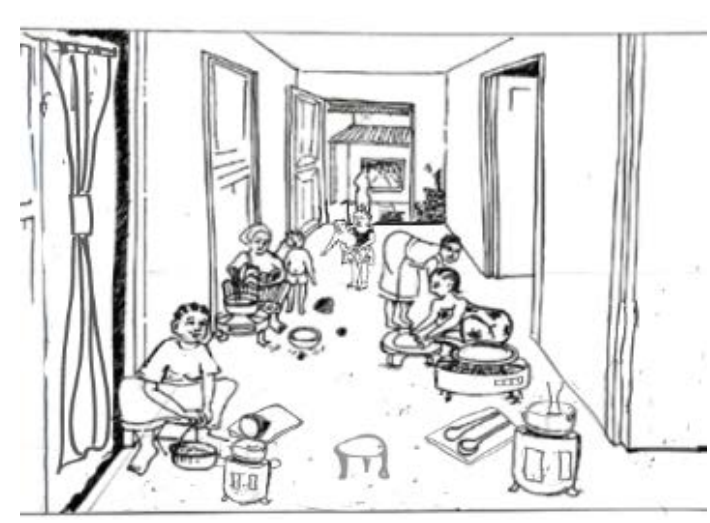

(a)

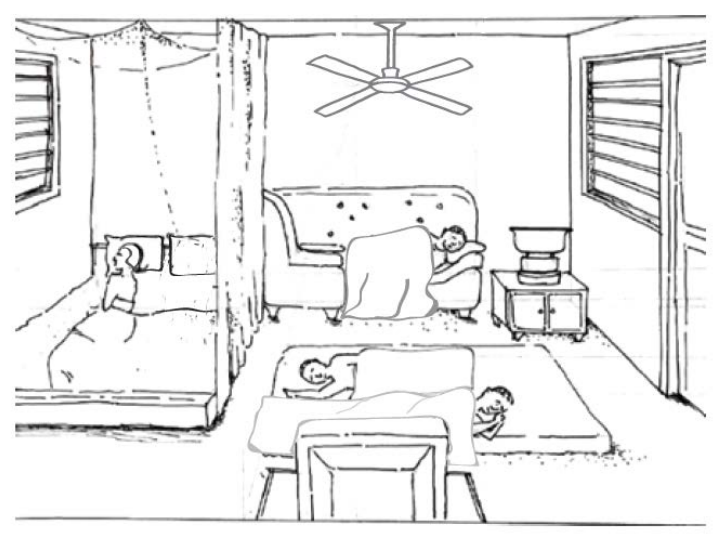

(b)

Source: Author's Fieldwork 2020.

Figure 10. Collective spaces at corridor and room. (a) Collective space at corridor; (b) collective space at room. 
collective aesthetic of the informal settlement. And this has commented by the scholar John Turner (1967) in the improving of informal settlement in Latin America. Informal settlements have their own identity and aesthetics that differs from formal settlements and this creates that value of this areas government and actors should avoid slum clearance (John Turner, 1967; Van Ballegooijen \& Rocco, 2013). However, this article has also documented social and cultural support even in space transformation activities. Also, space adaptations and access to different spaces have revealed resident to survive but also to have ability to perform activities that support community welfare. In spite of the challenges in informal areas, it is these enriching activities and practices that have led to satisfaction and better living experiences among residents in Mlalakuwa in Dar es Salaam but also in different other informal neighbourhoods. Certainly, these underscore the social and cultural relevance of informal practices, which are capturing attention in the current discourse of improving slums to attain the Global Sustainable Development Goals agenda (United Nations, 2015). The research suggests that developers including urban planners, designers and authorities should consider the social-cultural values in implementation of various developments in informal settlements.

\section{Recommendations}

Social-cultural diversity considered important factors in the community lives because they provide a solid foundation for the development process. It is also clear that professionals like planners and designers understand clearly the positive implication of social-cultural diversity in planning and designing process but they seem not often involved or available to improve the liveability of the collective spaces in informal settlements. In order to impart knowledge on social and cultural diversity in the design process the following recommendations are regarded important; Government must demonstrate the political will accept social-cultural values to be included in the design process objective of mitigating standard design which compromises with real situation in informal urbanisation. Development actors including authorities, planners and designers should play their role in creating policies that will include social-cultural values in the informal urbanisation.

\section{Conflicts of Interest}

The authors declare no conflicts of interest regarding the publication of this paper.

\section{References}

Abebe, F. K. (2010). Modelling Informal Settlements growth in Dar Es Salaam, Tanzania. University of Twente.

Borret, K. (1996). On Domains the Public, the Private and the Collective. Brussels.

De Solà-Morales, M. (1992). Public and Collective Space: The Urbanisation of the Private 
Domain as a New Challenge (pp. 3-8). Oase.

Debord, G. (1981) Introduction to a Critique of Urban Geography. In K. Knabb (Ed. and Trans.), Situationist International Anthology (pp. 5-8). Bureau of Public Secrets.

Duvail, S., \& Hogan, R. (2005). Apport de la cartographie à la gestion locale des resources renouvelables dans les villages du district de Rufiji (Tanzanie). http://journals.openedition.org/norois/410

Fao (2008). Land Access in Rural Africa: Strategies to Fight Gender Inequality. Belgium

French, C. D., et al. (2011). Culture and Social Development.

Gurney, M. F. (1990). Collective Space and Optional Associations. University Housing at MIT.

Gutierrez de Peneda, V. (1975). Familia Culturaen Colombia. Instituto Co lombiano de Cultura.

Hernandez, D. O, \& Titheridge, H. (2015). Mobilities of the Periphery: Informality, Access and Social Exclusion in the Urban Fringe in Colombia. Journal of Transport Geography, 55, 152-164.

Jones, P. (1997). The Impact of the Socio-Cultural Order on Urban Management in the Pacific Island. Unpublished PhD, Department of Geographical Sciences and Planning, University of Queensland.

Jones, P. (2014). Informal Urbanism as a Product of Socio Cultural Expression: Insights from the Island Pacific. UN-Habitat Cairo University Responsive Urbanism in Informal Areas. Department of Architecture, Faculty of Engineering, Cairo University.

Kamalipour, H. (2016). Forms of Informality and Adaptations in Informal Settlements. International Journal of Architectural Research, 10, 60-75.

Katz, P. (1994) The New Urbanism: Toward an Architecture of Community (pp. 4-19). McGraw-hill.

Kellect, P. (1999). Cultural Values and Housing Behavior in Spontaneous Settlements. Journal of Architectural and Planning Research, 16, 205-224.

Kironde, L. (1995). The Evolution of the Land Use Structure of Dar es Salaam 1890-1990: A Study in the Effects of Land Policy. Ph.D. Thesis, Nairob: University of Nairob. https://halshs.archives-ouvertes.fr/tel-01265022

Kombe, W., \& Kreibich, V. (2006). The Governance of Informal Urbanization in Tanzania. Mkukina Nyota Publishers.

Kombe, W. (2017). Institutional Reforms for Urban Land Use Planning and Management in Sub-Sahara Africa: Evidences, Gaps and Prospects. E\&D Vision Publishing Ltd.

Kruse, H., \& Torstensson, L. (2011). Vertical Extensions of the Urban Swahili House a Proposal for a Standardised Two-Storey Construction. KTH, the Royal Institute of Technology.

Kyessi, A. G. (2002). Community Participation in Urban Infrastructure Provision: Servicing Informal Settlements in Dar es Salaam. SPRING Research Series, No. 33, University of Dortmund.

Lefebvre, H. (1991). The Production of Space (p. 6). D. Nicholson-Smith, Trans., Blackwell.

Limbumba, T. (2010). Exploring Social-Cultural Explanations for Residential Location Choices: The Case of an African City_Dar es Salaam. Doctoral Thesis in Beuty Environment Analysis.

Luc, C., Joachim, W., Bert, I., \& Ravi, K. (2018). Migrants, Towns, Poverty and Job: In sights from Tanzania. Policy Research Working Paper, No. 8340, World Bank. 
Luhikula, G. (1998). Tanzania Coastal Management Partnership.

Lupala, A. M. (2002). Peri-Urban Land Management in the Rapidly Growing Cities, the Case of Dar es Salaam. University of Dortmund.

Makundi, L. M. (2014). Interior Composition of Traditional Dwellings in Tanzania: The Case of Chagga in Mamba, Moshi-Kilimanjaro. (Unpublished Dissertation)

Makupa, E., \& Alananga, S. (2018). Compulsory Land Acquisition and Good Governance: An Assessment of the Luguruni Satellite Town Project in Dar es Salaam Tanzania. PhD Thesis, Socio-Economic Impacts of Compulsory Land Acquisition Programs in Tanzania.

Marete, M. E. (2016). Role of Infrastructure in Urban Slum Transformation. Urban and Regional Planning, Department of Spatial Planning and Design, The Technical University of Kenya.

Mng'ong'o, O. (2004). A Browning Process: The Case of Dar es Salaam City. Doctoral Dissertation, Swedish University.

Muke, J., Denham, T., \& Genorum, V. (2007). Nominating and Managing a World Heritage Site in the highlands of PapuaNew Guinea. World Archaeology, 39, 324-338. https://doi.org/10.1080/00438240701464947

Myers, G. (2011). African Cities Alternative Visions of Urban Theory and Practice. Zed Books.

Nguluma, H. (2003). Housing Themselves-Transformation, Modernisation and Spatial Qualities in Informalsettlements in Dar es Salaam, Tanzania. Doctoral Thesis, Royal Institute of Technology (KTH).

Pallangyo, D. (2007). Environmental Law in Tanzania: How Far Have We Gone? Law, Environment and Development Journal (LEAD Journal), 3, 26-39.

Parnell, S., \& Pieterse, E. (2014). Africa's Urban Revolution. Zed Books Ltd.

Phillips, S. (2002). Social Capital, Local Networks and Community Development. In C. Rakodi, \& Tony Lloyd-Jones (Eds.), Urban Livelihoods, A People Centered Approach to Reducing Poverty. Earthscan.

Rweyemamu, V. V. (2013). Informalizing Formal Urban Settlements: The Case of SinzaDar Es Salaam. Un Published Master's Thesis.

Saunders, P. (1989). The Meaning of 'Home' in Contemporary English Culture. Housing Studies, 4, 177-192.

Scheerlinck, K. (2013). Collective Spaces Streetscape Territories Notebook. Streetscape Territories Notebooks, LUCA School of Arts.

Schoonjans, Y., \& Zhang, Y. (2020). Theoretical Development of Collective Spaces and Its Interplay with Urban Life. Beijing Planning Review, 191-195.

Sheuya, S. A. (2010). Informal and Finance in Tanzania. United Nations Centre for Human Settlements, Human Settlements Financing Tools and Best Practices Series.

Shubira, L. K., \& Daniel, A. M. (2018). Developers' Preferences to Types of Emerging Landed Properties in Informal Urban Settlements: Case of Mlalakuwa-Dar es salaam. International Journal of Development Research, 8, 20027-20034.

Swantz, M. L. (2013). Poverty in Local Government in Tanzania: A Rural Development Perspective. The African Review: A Journal of African Politics, Development and International Affairs, 40, 162-190.

Turner, J. F. C. (1967). Barriers and Channels for Housing Development in Modernizing Countries. Journal of the American Institute of Planners, 33, 167-181.

https://doi.org/10.1080/01944366708977912 
UN-Habitat (2004). Cities without Slums Sub regional Programme for Eastern and South ern Africa, a Memorandum of Understanding with the Government (Ministry of Lands and Human Settlements Development) Which Sets a Framework for Cooperation and Guidance for the Implementation of This Programme in Tanzania.

UN-Habitat (2011). Cities and Climate Change Global Report on Human Settlements 2011 United Nations Human Settlements Programme.

United Nations (UN) (2015). The Millennium Development Goals Report 2015.

United Nations General Assembly (UNGA) (2011). Political Declaration of the High-level Meeting of the General Assembly on the Prevention and Control of Non-communicable Diseases. President of the General Assembly.

United Republic of Tanzania (URT) (1999). Land Act. Government Printers.

United Republic of Tanzania (URT) (2013). Population and Housing Census: Population Distribution by Administrative Areas. National Bureau of Statistics, Ministry of Finance, Dar es Salaam and Office of Chief Government Statistician, President's Office, Finance, Economy and Development Planning.

Van Ballegooijen, J., \& Rocco, R. (2013). The Ideologies of Informality: Informal Urbanisation in the Architectural and Planning Discourses. Third World Quarterly, 34, 17941810. https://doi.org/10.1080/01436597.2013.851890

Wenban-Smith, H. B. (2014) Population Growth, Internal Migration and Urbanisation in Tanzania. International Growth Centre.

https://www.theigc.org/publications/workingpaper/urbanisation-tanzania

World Development Report (2020). Trading for Development in the Age of Global Value Chains. 